\title{
Assessment of the public protection of the legal interests of co-owners
}

\author{
I. Kudeikina
}

Rīga Stradinsš University, Riga, Latvia

\begin{abstract}
Each right is valuable if it ensures the legal interests of a rightholder to the maximum extent possible. The legal system must develop and maintain tools that would facilitate the effective exercising of lawful rights.

Public registration is one of such tools. This is a means of legal protection ensuring the right, making it known to and binding on third parties.

In the case of legal relationships concerning encumbered properties, it is particularly vital for co-owners to safeguard their interests and rights in both mutual and third-party relationships. Equally important is the protection of third-party interests in transactions involving an individual co-owner or a group of co-owners.

This research analyses the necessity of public registration of individual rights of co-owners associated with real estate (e.g. pre-emptive rights, divided use of co-owned property).
\end{abstract}

Key words: rights of co-owners, public protection of rights, Land Registry

\section{Objectives and methodology of the thesis}

The objective of the thesis is to research the possibilities and usefulness of the public registration of individual rights of co-owners in order to answer the question whether public registration could ensure more effective protection of rights.

To this end, both descriptive and analytical methods have been employed. The author has relied on laws, opinions of legal scholars and Land Registry data.

As regards co-ownership, legal relationships can be characterised as a particularly complex issue because any transaction gives rise to such relationships both among co-owners and between co-owners and third parties, thereby leading to enhanced requirements as to the safety of transactions. In addition, the requirements referring to the target of a transaction, i.e., real estate, must be met because, according to the legal scholar James Charles Smith, a distinguishing feature of private property is that it structures relationships not only between individuals, but also between organisations and individuals, such as the government, public authorities (James Charles Smith, 2013).

In this respect, the Land Registry should be mentioned as a public authority concerned. According to Section 1 of the Land Registry Law ${ }^{1}$ the registration of immovable properties and rights to them with the Land Registry is mandatory.

According to this law, entries of the Land Registry are viewed as official records; therefore, the objective of public registration is to safeguard the legitimate interests of

\footnotetext{
1 Zemesgrāmatu likums: Latvijas Republikas likums, adopted on 22.12.1937, entered into force on 05.04.1993. Published: Latvijas Vēstnesis, No. 11, 08.04.1993.
} 
right-holders. We should agree with R. J. Smith that the objective of registration is to protect both owners from potentially illegal acts of third parties and third parties from threats that could be caused by real estate owners in transactions (Smith, R.J., 2006).

Having analysed co-ownership and rights that could potentially be registered with the Land Registry, the author has concluded that problems associated with the agreement on the divided use of co-owned property have been the main focus of discussions recently. Would public registration ensure better protection? To answer this question, it should be first established what legitimate interests of co-owners and/or third parties would be safeguarded and what threats would be prevented by means of an entry made in the Land Registry concerning the divided use of co-owned property. The right of the divided use of co-owned property is provided by law, and namely Section 1070(1) of the Civil Law. ${ }^{2}$ The systemic interpretation of the law leads to a conclusion that the divided use of co-owned property as a right in rem is safeguarded regardless of whether or not any entry is made in the Land Registry; hence, public registration is not essential.

The analysis of the terms "divided use of co-owned property" and "agreement on the divided use of co-owned property" has demonstrated that they are not identical. The divided use of co-owned property is a statutory right of each co-owner. Meanwhile, the agreement on the divided use of co-owned property is an individual legal act containing the declaration of intention by co-owners concerning the division of the use of co-owned property, whereby each co-owner is assigned a right to use a physical share of the real estate in proportion to his undivided interest. The agreement on the divided use of co-owned property establishes a personal right. It should be noted that this thesis has not yet been widely accepted by legal scholars.

Agreements on the divided use of co-owned property have been registered by the Land Registry without any objections for quite a long time, thereby becoming official records. This procedure is merely a result of established practice because, as it should be emphasised, there exists no law that would deal with legal effects of the agreement on the divided use of co-owned property or the related registration procedure. The Chamber of Civil Cases of the Supreme Court of the Republic of Latvia was first to note these circumstances when it recognised as reasonable a decision taken by a judge of the Land Registry Department to refuse registration of the agreement on the divided use of co-owned property ${ }^{3}$. Legal relationships arising out of the agreement on the divided use of co-owned property have the nature of a personal right because claims refer to a particular person, which is inherent in a personal right (Скловский, К.С., 2003). This conclusion can be supported by applying the legal simulation method by visualising infringements of law that could result from a breach of the agreement on the divided use of co-owned property. It is evident that those could be infringements associated with the use of co-owned property (which is not possession because laws do not provide for any co-owners' rights to agree on divided possession and possession matters cannot be regulated by the agreement on the divided use of co-owned property), such as the management, use and maintenance of co-owned property. Disputes in this field, such as arbitrary or non-conforming occupation of the physical share, are not dealt with either by practice or by scientific literature. Therefore, any claims concerning the failure to comply with the procedure of using the property or other infringements arising out of the relevant agreement should be brought against the co-owner in default according to contract law.

2 Civillikums. Trešā daļa. Lietu tiesības: Latvijas Republikas likums, adopted on 28.01.1937, entered into force on 01.09.1992. Published: Valdības Vēstnesis, No. 44, 24.02.1937.

${ }^{3}$ Latvijas Republikas Augstākās tiesas Civillietu tiesu palātas lēmums lietā Nr. PAC-1209 [viewed on 06.05.2015] Available on: https://www.zemesgramata.lv/?cid=103. 
Situations when the non-registration of the agreement on the divided use of co-owned property would impair the rights of third parties are not discussed as well. It is understandable given that the essence of co-ownership rights per se determines the subject of a transaction, i.e., a transaction always involves undivided interest. For instance, a buyer may only acquire undivided interest, and no physical share of a property can be bought even if the use of a co-owned property is divided between co-owners. Overall, the existence of the agreement on the divided use of co-owned property and an official entry in the Land Registry does not refer to the subject of a transaction, nor can it produce any impact thereon. Above mentioned leads to the conclusion that the public registration of the agreement on the divided use of co-owned property will not enhance the protection of third party interests.

However, the analysis of the problem would indeed be incomplete without discussing the public registration of the agreement on the divided use of co-owned property regardless of its legal nature. There is an opinion that agreements on the divided use of co-owned property should be registered with the Land Registry because the relevant right supports the right in rem and, therefore, any agreements between co-owners on the procedure for using real estate should be registered with the Land Registry as a right pertaining to real estate. ${ }^{4}$ The author shares this opinion from the viewpoint of usefulness because public registration would minimise controversial interpretations and contribute to the development of a uniform practice. It is also emphasised in scientific literature that dispute prevention and mediation are essential for contemporary legal systems (Steven Vago, Adie Nelson, 2014).

Support may only be provided by means of the delegation by the law-giver via a relevant law. The proper legislation laying down the registration procedure and related legal effects is a precondition for the registration of agreements on the divided use of co-owned property with the Land Registry. The author is of the opinion that the public registration of agreements on the divided use of co-owned property should be a means of the effective, comprehensive and lawful establishment of legal relationships among co-owners and with third parties in the case of the divided use of co-owned property rather than an objective. The requirements of the contemporary world should be taken into account, legal scholars are increasingly inviting to give up dogmas, including the evaluation of rights (also property rights) from the viewpoint of precedence; instead, they suggest following reasonable uniform requirements, stressing that legislative innovations affecting security interests do not destroy or restrict property, they change the rules and institutions within which the property system operates. Property measures, whatever their institutional form, should be evaluated on their capacities to enhance human welfare, including liberty and economic incentives. There are no barriers between the public and private dimensions of property (J.Peter Byrne, 2011).

Such a law would be particularly necessary because the public registration of agreements on the divided use of co-owned property should be regarded as an exception to the numerus clausus principle and these agreements have the nature of a personal right. The numerus clausus is one of the fundamental principles of property law, forming its institutional framework (Jan Wilhelm, 2002).

It is not necessary to change the underlying principles of property law if the objective can be attained otherwise, namely by amending the legislation to provide that co-owners may agree on the granting of the right to use a certain share of the co-owned property and the relevant agreement should be registered with the Land Registry. This is a de facto situation, and the adoption of the relevant law would render legal relationships de iure.

${ }^{4}$ Latvijas Republikas Augstākās tiesas Senāta Civillietu departamenta 2011.gada 2.novembra lēmums lietā SKC-781/2011 [viewed on 06.05.2015] Available on: http://at.gov.lv/lv/judikatura/judikaturasnolemumu-arhivs/senata-civillietu-departaments/hronologiska-seciba_1/2011-hronologiskaseciba/. 


\section{Results}

As a result of the research, the author has arrived at the following:

1) The objective of public registration is the protection of rights by means of the public register set up and maintained by the State;

2) The objective of public registration is not the public protection of every right;

3) The approach employed in the registration of rights with the Land Registry is inconsistent, because different solutions are available for similar legal relationships;

4) The role of public registration in the protection of co-owners' rights is insignificant;

5) Public registration does not affect the protection of third-party rights in transactions with co-owners.

\section{Conclusions}

The importance of the public registration of certain co-owners' rights, such as pre-emptive rights and the divided use of co-owned property, is a mere fiction from the viewpoint of legal protection. The registration of these rights with the Land Registry does not bring any advantages over non-registered rights. In practice, the registration with the Land Registry has always been treated as important, which, however, is not supported by law and contradicts the theory of public registration for the safeguarding of interests. The previous interpretation has been erroneous. It is based on the current global tendency to involve public authorities for the protection of interests, thereby shifting off responsibility.

\section{Proposals}

Having analysed the insignificant role of the public registration of agreements on the divided use of co-owned property in the protection of rights, despite their nature of a personal right, and compared these considerations with the legitimate expectations of right-holders regarding the public registration of agreements and the well-established practice, the author still would like to suggest legitimising the agreement on the divided use of co-owned property by means of a law that would lay down the procedure for the registration of these agreements with the Land Registry and related legal effects.

\section{References}

[1] Byrne, J.P. (2011) The Public Nature of Property Rights and the Property Nature of Public Law. In: Malloy, R.P., Diamond, M. (eds.) The Public Nature of Private Property. Farnham, Surrey, England; Burlington, VT: Ashgate, pp.1-12.

[2] James Charles Smith (2013) Property and Sovereignty in the Twenty-First Century, In: Property and Sovereignty. Legal and Cultural Perspectives, Edited by James Charles Smith Ashgate Publishing Limited, 2013, pp. 1.

[3] Smith, R.J. (2006) Property Law. Harlow, England: Pearson/Longman, 2006. pp.219.

[4] Steven Vago, Adie Nelson (2014) Law and Society, Pearson Canada Inc., pp.29

[5] Wilhelm, J. (2002) Sachenrecht/ von Jan Wilhelm. 2., neubearb.Aulf. Berlin; New York: de Gruyter, S.5

[6] Скловский, К.С. (2003) Гражданский спор: практическая цивилистика. 2-е изд., испр и доп. Москва: Дело, с.245

[7] Civillikums. Trešā daļa. Lietu tiesības: Latvijas Republikas likums, adopted on 28.01.1937, entered into force on 01.09.1992. Published: Valdības Vēstnesis, No 44, 24.02.1937. 
[8] Zemesgrāmatu likums: Latvijas Republikas likums, adopted on 22.12.1937, entered into force on 05.04.1993. Published: Latvijas Vēstnesis, No 11, 08.04.1993.

[9] Latvijas Republikas Augstākās tiesas Civillietu tiesu palātas lēmums lietā Nr. PAC-1209 [viewed on 06.05.2015] Available on: https://www.zemesgramata. $\mathrm{lv} / \mathrm{cid}=103$

[10] Latvijas Republikas Augstākās tiesas Senāta Civillietu departamenta 2011.gada 2.novembra lēmums lietā SKC-781/2011. [viewed on 06.05.2015.] Available on: http://at.gov.1v/lv/judikatura/judikaturas-nolemumu-arhivs/senatacivillietu-departaments/hronologiska-seciba_1/2011-hronologiskaseciba/ 